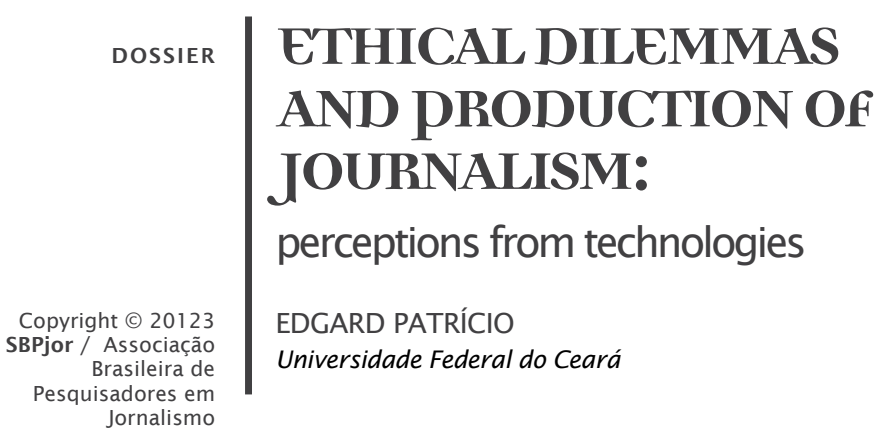

\begin{abstract}
The purpose of this study is to develop a reflection on ethics and practice of Journalism based on the production conditions of his professional exercise. It has been prepared in the basis of empirical material collected through the conduct of 15 interviews throughout the year of 2011 with professional journalists of the labour market of Fortaleza. Specifically for this study, I approach the relation between ethics, practice of Journalism and technologies.

Keywords: Journalism. Ethics. Technology.
\end{abstract}

\title{
DILEMAS ÉTICOS E PRODUÇÃO DO JORNALISMO: percepções a partir da tecnologia
}

RESUMO - Esse artigo desenvolve uma reflexão sobre ética e prática do jornalismo a partir das condições de produção do seu exercício profissional. Foi elaborado tomando por base material empírico coletado por meio da realização de 15 entrevistas ao longo do ano de 2011 com profissionais jornalistas do mercado de trabalho de Fortaleza. Especificamente para este artigo, trato da relação entre ética, prática do jornalismo e tecnologias.

Palavras-chave: Jornalismo. Ética. Tecnologia.

\section{DILEMAS ÉTICOS Y PRODUCCIÓN PERIODÍSTICA: percepciones a partir de la tecnología}

RESUMEN - Este artículo desarrolla una reflexión sobre ética y práctica periodística a partir de las condiciones de producción del ejercicio profesional. Se elaboró tomando como base datos empíricos recogidos en quince entrevistas con periodistas del mercado de trabajo de Fortaleza realizadas a lo largo del año 2011. En este artículo se trata específicamente de la relación entre ética, práctica periodística y tecnologías.

Palabras clave: Periodismo. Ética. Tecnología. 


\section{THE ETHICS, THE JOURNALISM AND THE JOURNALIST EDUCATION}

The problematic of ethics on Journalism is not a recent subject. But surely this agenda set more in evidence due to the transformations that has been suffering the production process of Journalism, inserted on the environment of communication technologies. How do the transformations in the production of Journalism resonate in the ethical dimension of his professional exercise? How do technologies impose other ethical constraints on that production? And how are the journalist realizing this relations?

One factor is triggering the need of a discussion about production of Journalism. And that need became more evident for the use of the internet a support of dissemination of that production. To Kucinski, there is in online Journalism "the primacy of the speed over other attributes of the information, as such the precision, contextualization, interpretation. Those attributes are sacrificed in behalf of speed" (KUCINSKI, 2004, pp. 97-98). Therefore, he corroborates the perception that one of the first ethical legacies which relates the journalist to his profession is the production of a good journalistic text, which incorporates the various ethical dimensions involved in its preparation.

The large amount of data available for journalists, through banks and databases available on the internet, is other element that flows through this discussion. The fact is the easy access to a great deal of information has given rise to a new segment of Journalism, the so-called "Data Journalism"; and a "new" format of informative genre of production, the so-called Computer-Assisted Reporting (CAR). Digital tools and languages are designed to account for treatment of such information. And once again, the accuracy of the technology and its use can degenerate into ethical lapses in the profession.

What is observed is that the ethical dilemmas faced by professional journalists establish a duality, an antagonistic view of thought and action, in determining what is ethical and moral. But this is not a question only of journalists. Costa (2009, p. 20) tells us that although "to the German philosopher Hegel, the ethics and morality were synonymous, for Kant, ethics would be superior morality. The ethics woul be within the public scope, more universal, and morality, in the private scope and subjective sphere ". But Boff $(2009$, p. 37$)$ is the one who launches parameters to the resolution of this antagonism. 
It deals with the real practice of people who express themselves by customs, habits and culturally established values. A person is moral when it acts in accordance to the enshrined customs and values. A person is ethical when it orients itself by principles and convictions. A person may be moral, and not necessarily ethical.

Now, even enshrined customs and values can be changed. To do this, the cultural transformations play a decisive role. Those potential transformations would be on the basis of the need of updating the ethical codes of various professional categories. The Brazilian code of medical ethics, for instance, states that its review should be performed mandatorily every five years. In that case, as was the case of the last review of Brazilian journalist's code of ethics, updates can be resulting from the advancement of the techniques and scientific discoveries that overarch the activity of the professionals.

But the fragmentation of knowledge may have led to this stratification of professional ethics. Again Boff (p. 42), in saying that "as the beings are unlimited, unlimited also are the knowledge. But (the reason) they forget that are parts of a whole. Fragmented reality begat fragmented knowledge and ethics fragmented in endless morals, for each profession (deontology), for each class and for each culture".

During 2011, the journalism course at the Federal University of Ceará, through discipline Journalistic Ethics and Practices, conducted a series of interviews involving 15 professional journalists operating in the labor market of Fortaleza. The guests were professionals representing the various media (print, radio, television, multimedia), of different occupations (reporters, editors, newsroom managers, company directors, teachers) from different workplaces (media companies, advisory firms and universities) and different age groups.

The testimonies, collected from group interviews conducted by students of the discipline, had on average three hours each. The scripts of the interviews, prepared in previous meetings, hinted at for questions about the relationship between ethics and social responsibility of the journalist; rapprochement between ethics and demand for the information of public interest; the ethics in the journalistic companies dimension, while linked to a public service; the relationship between ethics, technology and journalism; the mechanisms for monitoring and judging ethical lapses committed by professional journalists; the role of academic education in the preparation of the journalist for an ethical practice of the profession.

In addition to these questions, the professional journalists were invited to share with students the ethical dilemmas they experience or 
did experience in their professional practice of Journalism production. Regarding this last aspect, the different ages of the professional journalists invited to give their testimonies contributed to realizing the transformation of the relation between ethics and professional practice of journalism over time.

\section{A STRATEGY OF DISCUSSION ON ETHICS AND PROFESSIONAL PRACTICE OF JOURNALIST}

The discipline Journalistic Ethics and Practices are offered in the current curriculum of the College of Journalism at the Federal University of Ceará, in the 8th semester. This fact creates difficulties for professors who teach the discipline. In this semester, the last of the regular curriculum, almost all of the students are in the labor market, either as paid interns, either as professionals in diverted functions, but in the exercise of journalism. And they face the task of preparing its Work of Course Conclusion (Trabalho de Conclusão de Curso - TCC), that consists in drafting a paper or a practical work.

How does this situation affect the discipline didactic proposal? It must initially attend to the your program requirements which point to an intersection between theory and practice of Journalism. And necessarily, it has to address these specificities, a group of journalists in education attending to the last semester of their course. In this case, the proposal developed as from the semester 2011.1, when I took on the course, consist on an attempt to develop a didactic that 'take advantage' of these characteristics.

I grounded the didactic proposal in the premise that the discipline should be oriented to minimize the effort of the students, compared to the tasks that they have to take on that semester of the course. In addition, enabling the professional exercise already practiced by them could be 'brought' to the classroom, favoring the relationship between theory and practice, which is the aim of the discipline. And at the same time, the discussion could make a rapprochement between academic education and the labor market, since students would receive their diploma of journalists at the end of that semester.

I suggested to the students that we could perform a series of interviews with professionals in the labor market in which the relationship between ethics and professional practice could be spelled out. And the professionals could explain in that dialogue the ethical dilemmas they experienced in their career in the labor market. The class accepted the 
proposal, I suppose, because they realized the rapprochement between professional practice and ethical dimension, which they may already have faced while participants in the labor market, and, of course, because of the slightest effort that it would take to conclude the discipline. without studies or tests.

\begin{tabular}{|l|l|}
\hline Interviewee & Occupation \\
\hline 01 & Chief Editor of TV \\
\hline 02 & University professor of Social Communication \\
\hline 03 & Printed newspaper reporter \\
\hline 04 & Printed newspaper image editor \\
\hline 05 & Printed newspaper and blog columnist \\
\hline 06 & $\begin{array}{l}\text { Coordinator of an apocryphal digital bulletin that analyzes the } \\
\text { performance of Ceará Press }\end{array}$ \\
\hline 07 & Partner of a communications advisory company \\
\hline 08 & $\begin{array}{l}\text { Commentator of a TV news show and columnist of printed } \\
\text { newspaper }\end{array}$ \\
\hline 09 & Radio, TV and printed sport chronicler \\
\hline 10 & Communication advisor of a government institution \\
\hline 11 & TV presenter and reporter \\
\hline 12 & University professor of Social Communication \\
\hline 13 & Printed newspaper editor \\
\hline 14 & Printed newspaper reporter \\
\hline 15 & News portal editor \\
\hline
\end{tabular}

The didactic of the discipline entailed the appointment of professional journalists to be interviewed by the students themselves some names of interviewees were 'colleagues' in the labor market. Names selected, the class was divided into teams. Each team was responsible for collecting the information of the activity of such professional, for the production of a basic script of interviews and for the preparation of a journalistic professional profile. All these information were shared with the rest of the class that made its considerations about the material collected. In the next lesson, we conducted the interviews and did a review of the sperformances of the respondent and the class, already in preparation for the next interview.

All professionals were alerted to the fact that the interviews in their entirety or edited, could be part of a publication, as a result of the discipline. But because of commitments have not been collected in a formal way, and what could represent the opinions of these professionals in their working relationships, we chose not to mention their names. 
As a result, the statements of each of the professionals interviewed are listed in this article, from numbers. But we described their professional experiences at the time of conducting your interview, so you have an idea of the diversity achieved by the participants.

\title{
3 ETHICS, THE EXERCISE OF JOURNALISM AND TECHNOLOGY
}

The codes of ethics of professional activity suffer updates over time. This is a movement that attests to the adequacy of professional ethical conduct to social transformations. According to Camargo (2004, p. 34), the codes of ethics are "defined, revised and promulgated from the social reality of each period and each country, according to Campbell (2004, p. 34), though he points out that "broad lines", however, are "deduced from perennial and universal principles".

Camargo (2004, p. 32) further comprehends that:

\begin{abstract}
Professional ethics is the application of general ethics in professional activities, the person has to be imbued with certain principles or eigenvalues of the human being to live them in their work activities. On one hand, it requires deontology, i.e. the study of the specific duties that guide human conduct in their professional field, on the other hand, requires diciologia, i.e. the study of the rights that a person has to exercise their activities.
\end{abstract}

The latest revision of the Code of Ethics of the Brazilian Journalists happened in 2007, after 20 years of the last update. One aspect that 'forced' to update the Code was the increasing use of the procedure of hidden cameras for the production of journalistic reports of a more investigative nature.

Specifically for this study, I will not dwell on the discussion of the concept of ethics and their relationships, or superposition for some, with the concept of morality. Two reasons lead me to this option. The first, a practical one, is the physical space that I have to dissert about the subject of the article. The other option is that we try to relate ethics and professional practice of Journalism, based on the interviews, that was not a discussion that originally guided the scripts of prepared questions, leaving it to the professional journalists to freely weave considerations about both concepts, and use them from their own understanding2. Our perception is that harnessing the concept could cause an inhibition of the interviewees. 
When you do the analysis of the interviews, we find the relations established between ethics and production of Journalism. These relationships are mediated by certain categories, for which is concretized the journalistic act, permeated by ethics or its abandonment. Those would be the dimensions through which that relationship insinuates. One of those dimensions focuses on the concern of ethical concept by the journalist, who tries to make clear his concern to follow his precepts or attempting to identify the ethical lapse. Another dimension would be a denial of the concept of objectivity, by the news company itself, which forces the professional journalist to the ethical lapse. The identification of when ethics pervades the Journalism production is explicit when respondents are urged to report their procedures in the light of ethical concepts they defend. That would be one more dimension. Another would be the relationship between academic education, production of Journalism and ethics. Finally, there would be a dimension which part of the technology interferes in the relation between Journalism production and ethics. We will analyze the last two dimensions here.

\subsection{Academic education and ethics}

During the interviews, a unanimous orientation among professionals was to reiterate the importance of the discussion of ethics and professional practice of the journalist. To endorse this position, they established a relationship between ethics and professional training. The Interviewee 01 emphasizes this position when addressing to the Journalism students who did the interview:

\footnotetext{
You, indeed, are having the opportunity to learn something about ethics with professionals who are already in the market, who are a little longer than you in the market. You will take it for life. This experience, you are having it only because you are in the university. The ethics that I am talking about to you is the ethics in fact. The exercise of the journalistic profession today is like that. And I think a lot of experience of this real ethics makes even more valuable this time you are going through here in college. Why it is so fundamental, in my assessment, you have a diploma from the profession. It's something I do not really do without.
}

The speech of the interviewee inaugurates another discussion: at what point would it be important to discuss the ethics in the process of journalist education? According to Bucci (2002, p. 204), the ideal would be curricula that addressed "not only the existence of a discipline about ethics, but ethical commitment as the foundation of each of the disciplines." Through this perception, Bucci does not establish, within the 
construction of the curricular matrix, one linkage between discussion of ethics and professional practice, since the curricula of Journalism make a clear division between theoretical disciplines taught in the initial semesters of training courses, and practical disciplines, concentrated in the intermediate and final semesters of the courses.

The vision of the discussion about ethics diluted throughout the academic formation of a professional journalist, defended by Bucci, is echoed also among the participants of the dialogue with the students. But the rapprochement between conceptual discussion about ethics and the ethical dilemmas in professional practice opposes two positions. The first, which deposits at the time of academic education the largest brunt of discussion about ethics, as explained Interviewee 08 , when he says that the basis of ethics education professional "is in the course. This theoretical part in which you will discuss with the professional, this base is right here. In the professional environment, we will apply some things we consolidate here". Referring to the second position, Interviewee 02 bets on a rapprochement between the conceptual discussion linked to academic education and the professional practice.

\footnotetext{
Ethics is done in practice, but also from reflection. We're talking about the journalistic ethics that must be the result of everyday practice of professional activity, but also a permanent reflection through reading and debate with colleagues. Our profession is the one that mostly discusses the ethics and this is salutary.
}

This perception is also shared by Karam (2004, p. 129), which establishes an approach drawing attention to the fact that "journalistic formation and production require epistemological fundamentals, including ethical, technical and aesthetic considerations". In this case, the moral principles of the profession would gather, as a synthesis, a "shouldbe (deontology)" anchored in the quest for professional fulfillment and resolution of fact-problems which mankind recognizes as such, "from an accident to a deviation of public funds, from a tempting to its reasons to the interests involved in any conflicts or wars. "

And it is in the form of professional practice that journalists identify the importance of ethical discussion in the educational process. As clarifies Interviewee 03 first establishing his view over the mandatory diploma for practice of the profession.

I am in favor of the mandatory diploma for one simple thing: for pure corporatism, I assume that. Because I think weak the defense of those who are against and the defense of those who are in favor. 'Oh, because it is within the University where it is forged the entire history of ethics'. Well. Well. It comes from my family, it comes from the street where I lived, where I did this or that. 


\begin{abstract}
'Ah, many journalists are bad character'. Logically, but most, at least in my calculations, are good ones. (...) 'Oh, because medicine deals with life, any mistake and you can get someone killed'. And in Communication, can't we? Giving a wrong information there, you cause a riot in a prison, putting a history there in the middle deals with life, yes, it does!
\end{abstract}

A view supported by Caldas (2005, p. 88 ), when it emphasizes the power of the communicator, "to make and unmake contexts, to assemble and disassemble realities cannot prevail. We need to regain the ethics of individuals, professionals, institutions, citizen. To rescue the public sense of information and social responsibility of the communicator". The main discussion would rest "on the perception of power over the media discourse, its impact on public opinion, and especially in understanding the information as a public asset and not private." Hence the need to "revisit the education of the journalist as an intellectual on the interpretation of events and not as a mere reporter of facts with its multiple versions" (CALDAS, 2005, p. 88).

The importance given to the educational process in the appropriation of the ethical dimension of the profession can be measured in the perception of reality when the degrees of Social Communication did not exist. The Interviewee 09 was part of that moment, and his testimony is representative of this situation.

In Radio Uirapuru, we had a kind of code, where we directed our work. For example, expletive. Holy Mother! If I said a swear word on those radio, I would soon be fired! At that time there were principles. So our training was in practice. As for television, there was no TP (teleprompter), there was nothing. When I got to the TV Ceará, where I started, I knew nothing. I had left the Sea Dragon Radio, I got hired by Verdes Mares Radio, I would learn there. Then I got to the recording of the comrades doing the news show, I kept looking and watching. Pretty soon I was doing it too. That was how we were supposed to learn. At that time there was no Social Communication colleges. Then we learned it in the hard way. About the ethical principles, we would learn them in the same way.

Then, still on the ethical discussion on the process of education of the journalist, according to Chistofoletti (2008, p.15), in order to achieve a better Journalism it's not "only required the most modern equipment" for the communication systems, but, indeed, that there are educated "well the human resources who will populate the newsroom". It is "essential to think, discuss and disseminate an environment of ethical reflection in communication processes". 


\subsection{Journalism production and ethics}

\subsubsection{The rush of information}

The first ethical commitment of the journalist in his professional practice, should be with the dimension of the social responsibility of their profession. In this case, the public interest should permeate their practice. And the strategies to approach the production of journalism and public interest, necessarily involve the quality of the data he manipulates and produces. It is from the quality of this information it will be possible to measure their social reach their mobilization capacity and guidance to social change.

One of the processes that underlies the production of journalism is the search for the unpublished, hidden, unreachable to the public information. It is the journalistic "scoop", which gained momentum from the structuring of the media in communication companies. But a perverse relationship is established between the scoop and the speed of circulation of information. The faster information travels, the greater is the unleashed race of media companies around the scoop, in fear of being 'stuck' for competition and as a struggle to differentiate their product. It never hurts to add that scoop also affects the credibility of the media company and its product, that it builds among the general public.

One of the contributions of the internet to the production of journalism is exactly the increase of speed in the flow of information, which, for Interviewee 02, affects the ethical component of the profession.

\footnotetext{
Today there is an exasperation due to the journalistic scoop and exclusivity that is increasingly difficult, because of the internet. That exasperation leads some journalist to certain exaggerations: he frames as complaint what is not complaint, what is just a suspicion, then it's a suspicion that is not confirmed, but if treated as a complaint from the start, it indelibly stains the reputation of the people involved.
}

That is the discussion raised by Kucinsky (2004, pp. 81-82 ), drawing attention to the relationship between ethics and internet. For him, the internet creates new dilemmas beyond those existing in Journalism, mainly because it wrecked some boundaries hitherto well marked. The demarcation between 'personal communication and collective' became tenuous, and therefore between the concepts of 'public and private'. The internet knocked down the demarcation between 'information means and market', once you are able to search for a certain good for sale on a shopping website, and at the same time, you can effectuate the commercial transaction; it threw down the demarcation between the 
various languages of communication, as well as between the various media. Its contents are the most arbitrary as possible, and through the ease of copying, the internet virtually destroyed the concept of copyright and authorship itself. Therefore, it started to enhance the problems of information authenticity and veracity, means credibility and responsibility for the information.

But the same Kucinski (2004, pp. 22:23) will state that “(..) codes of ethics differ from country to country or from one period to another, precisely because they reflect changes in emphasis or in values articulation of ethical matrices from different cultures in various times. Of new habits come new values. "Will the internet generate new habits, which in turn wil be generating new ethical values? Are we not prejudging the relation between journalism and internet, and its ethical implications, with the eyes of previous values?

Christofoletti (2008, pp. 94-95) seems to support my questions by noting that "if technology modifies interpersonal relationships, it also changes the moral values and ethics. Therefore, it is necessary to hold a little in the movements that rattle the current times in order to understand how journalistic ethics is also changing". For better or for worse? That is another dilemma that settles and that our respondents anticipate so well. Let's go back to them, then, who experience in their workplaces and in practice of the Journalism production these new ethical dilemmas.

Interviewee 02 also draws our attention to other repercussions of this 'exasperation' caused by getting the journalistic scoop in one of the essential stages in the production of Journalism, the process of verification of information.

\footnotetext{
One of the concepts being most damaged on this new journey is the concept of journalistic accuracy. The vehicles are increasingly flooded of giving first hand information, and in that haste, they let go credibility, responsibility for what they're doing. The speed on which this thing happens, there's no time even to check if what they have as information is true or not, if that is confirmed. It becomes a contest of who will give the news first. But at the same time they are disputing who scored first, they are also disputing who errs first. It is all in the stakes and this is very risky in certain situations.
}

But if, in one hand, the companies and professionals earn credibility when they get the journalistic scoop, what they lose if the broadcasted information in "first hand" is not confirmed, due to the haste of information? Is it possible to establish a cost-benefit relation between rights and wrongs in this case? Is it possible to base the ethical behavior of Professional practice of Journalism on a relation of rights 
and wrongs? Interviewee 15 draws the attention to those discussions and brings up other elements to better understanding of those dilemmas, for example, part of her practice as an website journalist.

\begin{abstract}
I remember some situations like when the Portal Terra [ a news Portal www.terra.com.br] publishing the accident of a TAM1 airplane.. The news headline stated "a fire reached part of the Congonhas Airport, in this Thursday, in São Paulo. Soon more information". Then everyone came upon them. What did they mean with "soon more information"? Comments started to rain upon us, it was really frowned upon by the net and the media, it was a irresponsibility. Lots of people on travelling or with relatives on travelling wanting to know what happened. They didn't commit a mistake with the nature of the information, but even with the low accuracy about it, they decided to run it and publish it. What is the least of inquiry of a news so it's not a risk to publish it? The hardest part is that I know if I don't do it right, the audience reaction will be very negative. To get the scoop is nice because you get a great brut of retweets and repercussion. People will divulge that an accident happened on Congonhas Airport. But if I publicize a better inquired content, more structured, more detailed, with a photo of that incident in the Airport, for example, I exceed the amount of retweets instantly.
\end{abstract}

But even if mistakes or inaccuracies happen in the process of information inquiring, due to the aim to getting the scoop, the possibility of 'fixing' those mistakes has also risen because of the same technology development. But at least two factors surround the resolution of the journalistic error. First, the historic resistance of company and journalists to admitting they made mistakes. It's not any wonder that the space given to apologizing sections on the printed newspaper, for example, is really short. Or it doesn't even exist. And when they really apologize, the information are often incomplete, they don't refer to the mistake committed, that could contextualize the reader. They merely inform that 'otherwise we publicized yesterday...' the resistance to admitting the mistake can also be based on the weakening of the ombudsman experiences in the Brazilian communication means. And the account of the stormy relationship between the news editing and ombudsman has already filled many pages of books that approach that issue.

The other factor that surrounds the decision process in the resolution of journalistic errors is the fact that its fixing can lead to other dilemmas, of ethical nature. As Interviewee 15 explains.

There is the ease of correction. In the web portal, we make clear you have to do errata. Did you err? Then make the errata. But sometimes the journalist's ego, the intern's ego, makes difficult for them to admit the mistake for their editor, who sees and fix it when the report is already done. That is only one example of the performance of someone who is in the head of the news producing. There are editors who rather not to admit the mistake, because they think that it causes a negative impression. 
Interviwee 15 notices another ethical dilemma on the web journalism production, also associated to the rush on the circulation of information, which is related to the initial authorship of the information. The internet became a source of agenda, or even a source of copying information, among the various means. The place of television and radio towards the printed newspaper as a source of agenda was taken by internet, that became part of the television and radio agenda too. And the acknowledgement of the initial authorship of information still faces barriers

\begin{abstract}
For example, the newspaper 'O Povo3' published that Clodoaldo [professional soccer player from Ceará] signed a contract with Ceará [Sporting Club]. Then, 'Diário do Nordeste4' and 'Jangadeiro Online' starts racing after the information that $O$ Povo has publicized first, they checked with the board of directors and the fact was denied. We see a lot of this around here, and when I said to friends journalists that live outside, they were shocked... You try to inquire the facts to deny your competition. That's the first point. I think we give too much credit to that. Second point: if I attribute the initial authorship of the information to O Povo, I should write 'according to O Povo'. Unfortunately it's a very difficult to deal with, a product quoting another, Sadia quotes Perdigão [for example]. It's very rough, but it should be done. We see some American websites that quote the competition. The most we have accomplished in Brazil is what happened with Estadão, that on Twitter, it uses the web URL of the news website and adds 'by O Globo', for example. If the information started from there, they began the verification of it, and it should be written 'according to O Povo'. The Globo.com does that also, sometimes you can read 'according to Folha de S. Paulo newspaper'. But they do it the wrong way, because the right thing to do would be to post the original URL of the newspaper website. I mean, there's a serious issue of information and image copyrights, and it's very troublesome.
\end{abstract}

\title{
3.2.2 Technological instrumental
}

If the rush of information is a consequence of the technology evolution on the process of circulation of information, what can we state when the technological arsenal is used directly in the information production? There are also ethical repercussions. The use of the hidden camera, aiming to circumvent barriers to searching for information, frequently is a matter of discussion on the ethical relation and the professional exercise of Journalism, even before the dissemination of the internet as a support to the circulation of journalistic information. Its use by the journalists, among other factors, motivated the last updating of the Code of Ethics of Brazilian Journalist in 2007.

In his Article 11, subparagraph three, the code states that the journalist cannot disclose information 'obtained improperly, for example, with the use of false identities, hidden cameras or microphones, except 
in cases of undoubted public interest and when exhausted all other possibilities of investigation'. But what are the limits the journalist can reach to affirm that he has exhausted all the possibilities of investigation and he is allowed to use hidden camera, for example? In the current moment, when the contributions of amateurs filmmakers swarm on Brazilian television and internet, how to establish boundaries?

Anyhow, it's in the public interest, read or not in the Code of Ethics, that the Interviewees based their defense the use of those inappropriate means of information investigation, in which the technology plays a special role on the Journalism production. As Interviewee 01 affirms.

Recently, we made a report based on a shooting recorded with a microcamera on a grocery shop on my neighborhood, Carlito Pamplona. The guy was selling products with expired shelf life. We received a complaint of a person who got sick because of those products. It was the second reportage we made in these last few months about selling products with expired useful duration. In the day the report was going on air, the lawyer of the grocery shop called. He said, 'listen, I forbid you to air this report'. I said, 'you listen, honestly, you should forbid your client to sell this kind of products to people.' 'You don't understand anything of criminal laws'. 'I might not understand anything of criminal law, but of Journalism, I do, and the report is going to air'. And so it did. Regarding the microcamera, we recently caught a doctor who attended in a clinic, but his son was the real doctor, and the father wasn't. the father prescribed instead of his son. We called the regional Counsel of Medicine [Conselho Regional de Medicina CRM], obviously to protect ourselves, and we asked if the Counsel was already investigating the false doctor. That was one case that we used the microcamera. We produced a series of reportages about Dengue fever, but over a different spotlight. We showed like doctors of the government health system treated the disease. Then we plotted a perfectly healthy producer of us to tell them he was feeling some symptoms and he was attended by different doctors: governmental, private and in a specialized clinic. The only one who diagnosed it correctly was the specialized clinic's one. We only use the image of hidden camera when the felony is confirmed. A fact that we reported recently was a car park attendant selling cocaine. We showed his face. The guy was a drug-dealer. Is it a crime? We did show, but people consuming it, we didn't, because using drugs is not a crime under Brazilian law. That's an exercise of ethics on a daily basis. Obviously, we may have failed sometimes on that exercise, But we've been trying to follow this ethics on the Best way possible.

In the statement of airing information obtained with hidden cameras, the caution of using this technological apparatus only if 'crimes' are confirmed derives from a judiciary function that's not up to the journalist to carry out. Criminals are recognized as such after a due trial on a penal court. And it doesn't compete to the Journalism to forestall that trial, on the risk of slipping into another ethical slide.

(...) I follow the peculiarities of each case. I told I already had two experiences in this sense, one of them was bad, and it really wasn't worth. Anyway, I was working in other company, they asked me 
to make a reportage with a hidden camera, for TV then (I worked for a TV channel). And not questioning anything, thanks God, it didn't work out, I filmed it all in wrong angles, I filmed the skies, but then I saw it didn't make sense, because it was a clandestine abortion clinic. Latter I found out that it belonged to a friend of the broadcasting company's owner. And, anyways, hopefully it didn't work out. I went there, and only filmed the sky. On the second time I used hidden camera, I did it for a printed newspaper, I did it consciously. Then I get to thinking, did I do wrong or right? It wasn't a investigative report. It was about the HGF3, some said the HGF was reformed and after six months, it was already full of people on the ER's and in the halls. Then I called to the advisor, 'listen, I'm doing report about that, may I come today?'. She said, 'no, you can't, come tomorrow, because someone is busy', ' but I can't...', 'No, come tomorrow'. Then I said, 'All right. Tomorrow, at 9 AM?', 'tomorrow at 9 AM?'. Then I hung up the phone, 'I'll go now!'. Then I went there, I didn't identify myself as a reporter, just to see the real situation. I got in front of the hospital and walked towards the ER's. I saw everyone in the hallways and there were a lot of stains on the walls, serum fixed with sticking plasters, people crying out of pain, all that mess. So I observed all that, not addressing as a reporter. Then I talked to some people identifying myself and came back to the newsroom. The next day, where there were fifty stretchers, there were only 10 in the hallway, there was no sticking plaster, a bunch of doctors assisting every patient. Then I talked to the director of the hospital and confirmed with her, 'yesterday I was here and saw a whole different situation. What do you have to say about it?'. Then I get to thinking, did I do wrong on using the hidden camera? If I had only come (on the day the hospital advisory appointed), would I have seen the reality of the facts? I entered there not identifying myself as a reporter, but people I interviewed as a reporter helped to confirm that the reality wasn't the one they were trying to show, that all that stuff was made up. So I don't know that we have to analyze each case. Depending on the way you use it, you are not doing anything wrong.

\section{Other problem of the using of hidden camera and other instruments questioned by the ethics in the exercise of Journalism are the tenuous boundaries between the public interest and the communication company interest for a larger audience to its products or even more particular interests that surpass the merely commercials aims of the obtained information, as such as to annoy people or institutions that somehow may cause troubles to its operation. Interviewee 06 exemplifies.}

A wiretapper was put on the attorney general's office here, in Ceará. Jangadeiro3, till then, publicized recordings even without the proper judiciary authorization. AS the fact involved the AG's office and two attorneys more directly, the broadcasting company used a biased method, 'if someone not really known was involved, we disclosed the recording. But as very important attorneys are involved...'. Regarding the ethics, I think that if we can't put all of it into practice, then we should put nothing of it. I believe that even some points of the Code of Ethics, despite of being recent, should be updated. (...) If there was a hidden camera or a audio recording that proves a felony or confirms a news, the boundaries of the ethics or of the legality of the using of such materials can be used to hinder its disclosure. We have a opposite view, the recording, even though illegal, may serve to the public interests. 
The hidden camera has a function in the phase of information research. But technology, as instrument, can also be related to the treatment of the journalistic information, in the moment of its transmission. In the image editing, the ethical issue goes far before the emerging of internet. But the software of image edition forced a debate about the limits of its usage. In certain moments, its use seems to be free of the ethical dilemmas. For example, the edition that edits the image to highlight the main information. But what can we affirm about the photo editing the turn, accidently, female bellies on to planed surfaces, lacking a navel, in exchange of eliminating the sings of cellulite? If details can be withdrawn, many times without leaving any traces, other details can also be inserted in situations where originally they weren't, and they can compromise the integrity of the journalistic facts.

\subsubsection{The Interaction}

But the relation between technology and Journalism production can also create spaces where the defense of ethics in the professional exercise are required, and the ethical lapses are better watched. The web journalism production allows a more honest interaction process between producer and receptor of the information. In some instances, we may confuse which role each of them is playing. That possibility permits a more active participation of who has the access to the journalistic information in the ethical inquiry of who produces it. Interviewee 15 brings up a report of how it happens.

Erstwhile, on the web, we were concerned about the audience will remember who publicized that first. But nowadays, they will remember who publicized it better. (...) What lasts in peolple's minds is a evaluation of the best report. So, sometimes, it's better for us to hold up, to structure and produce the best. It's also important to have the picture, to struggle for the photograph. Even though I publicized it one hour later, if I get the photograph, I get the highlight.

And what can happen if the journalistic information does not fully correspond to the reality?

But it's the same deal. It remains the comment, 'wait up, you said something else not so long ago'. Then you think, 'no, don't let this comment go to the website. Delete it!'. Whom are you going to deny it to? The person goes to the Twitter and says, 'Sad for you! @ webportal publicized something wrong, didn't correct it and even deleted my comment. Why haven't you approved my comment?'.

Interviewee 15 says that the delay in the correction of information may arouse the positioning of the internet users towards the repairing 
and apologizing of the responsible for the publishing, making it a even more wearing process for the company the longer it takes to repair it.

It's really frequent the users comment and wait for the approval. If it takes one minute, the immediately send another comment, 'why is it taking so long to approve my comment?'. I wish I could reply and say, 'because we are a small team and we receive 400 comments per day, and we can't hire someone just for doing that all the time'.

But the speech of those who are still manipulating the information persists, even in the web journalism, what creates an unsteadiness related to the ethical dimension of its exercise, even in so modern times. Again Interviewee 15.

Another ethical issue: you create the space for comments and you delete the critics. The policy is crystal clear: 'offensive comments, swear words or biased speeches'. There's the anonymity. The means of web communication should abolish this anonymity issue. I mean, 'do you want to comment? Do ir, but who are you?'. The professional needs to understand that it matters more a comment of quality then 300 ones, which most part are comments making fun of soccer clubs. They add nothing to your website. It's complicated that commenting issue, because the journalist himself approves [the comments], it' not an ideal method. He may have some interests deleting some comments, editing another in favor of his own report, qhat complicates even more the issue.

Though the interaction allows some control over the veracity of the information, and, wherefore, it contributes for the strengthening of ethical standards of Journalism production, the defense of a 'pseudointeraction' is changing some procedures of investigation and negatively influencing the presence of ethics in the professional exercise. It already happens, for example, on the production and dispatch of 'releases' of the communication advisory companies for the communication means. On one hand, this procedure make the professional to spend more tie in the newsroom than in the 'alluring soul of the streets'. On the other hand, the software of messenger managing and text editing ease greatly the simple transposition from the 'release' to the journal edition, the so called 'copy and paste' or ' $\wedge \mathrm{C}, \wedge \mathrm{V}$ '. even the journalist on the urge of the quick information allows himself to proceed interviews through e-mails.

The virtual interaction also strengthens the feeling of accommodation in the journalistic investigation process, what can be verified on the quality of the broadcasted information. That's what Interviewee 05 states.

When it's a local matter, I do it myself. I trust in my sources, I get it, confirm all of it. For example, a very simple, quick, example you're a advisor and calls me up, 'Interviewee 05, I'm going to send you a release'. I say, ' listen, send me a release, but once you're here, 
let's construct the information'. I love to do it, because sometimes we, users of internet, get to impersonal, and I like to talk to people, because I get to feel their feelings. By the voice, when you get some experience on it, you get to know if someone is good or not.

It's interesting this double definition of the Journalism on the internet. Beyond a manicheaist or a dichotomist vision, sometimes it advances allowing a bigger participation on the process of Journalism production, when even the notions of producer or receptor are confused; sometimes it retreats, when the internet is used as a technological support that leads to serious repercussions in the journalistic procedures, that nowadays lack the face to face interaction. That's what Kucinski (2004, p. 86), affirming that internet

(...) is also a new custom, a habit. The customs are determinants of the ethical values. The internet, paradoxically, is the space where the phenomena of fragmentation of ethics is better experienced in our times, but also, the ideal refugee of the libertarians, of those who have not surrendered.

All those dilemmas afflict Costa (2009), that tries to summarize the new ethical conditionings brought by the new media environments: the control over the web (domains, for example), concentration, professionalization, convergence, convergence on cell phones, mechanisms of global search, information accuracy, journalism and entertainment, new reality of advertisement, contextual marketing, collaborative content, prosumer, emergence of the reporter individual, emergency of the reporter citizen, hearsay, copyrights issue, not remunerated work, sources.

The same thoughts has Christofoletti (2008, pp. 96-100), who adds items to the list, almost entirely remembered by the Interviewees: the ease of access to a great amount of information. And a great amount of information might reinforce the credibility principle; plagiarism of productions may be facilitated, once there's access to a worldwide Journalism production; the speed of information production. Or it might minimize them, for example, in the phase of investigation; the chain of mistake/error amplifies, because radio and TV use as source of information the internet; the ease of correcting incorrect information, not alike in the printed Journalis; the ease of the image editing.

\section{PERSPECTIVES FOR OTHER DISCUSSIONSS}

The implications we deduced here state that Journalism is going through many transformations. The technology plays a decisive role in 
that process. Due to those changes, old ethical dilemmas are reinforced, while new ones come up. Many doubts project, but one certainty sees to organize this apparent chaos: the new ethical dilemmas around the Journalism production are about to come. And what do these new dilemmas suggest? For Kucinsky (2004, p. 24), on that new environment, "[...] the socially constituted ethics give place to ethics defined by each individual, which seems a contradiction in terms, a paradox, once the personal behaviors can only be evaluated in their comparison to other behaviors'. Each individual, '[...] in these postmodern times, would have the faculty to decide his own behavior, to cultivate his own values. It's a return to the most fundamental of all the ethical issues: the questioning of whether exists ethics or not'. Would we be fated to live together with 'individual' ethics? In Journalism, how to conciliate social responsibility of the profession, which comprehends a collective understanding in the social process, and individual ethics?

More and more we should remember Goodwin (1993) and his baffling questions when we face dilemmas that show up as ethical for us, however we should reflect over these same questions considering this environment of Journalism production we began to experience: 1) What do we usually do in similar situations? 2) Who will be damaged or helped? 3) Are there better alternatives? 4) Will I be able to look at myself in the mirror again? 5) Will I be able to justify my actions before the people and public? 6) Which principles or values should we apply? 7) Does that decision fit the kind of Journalism I believe?

We hope to give our contribution to those dialogues, based on our experience with the Interviewees, that have pointed out so well the relation between Journalism production and professional ethics. They are the ones that on the daily work make these questions to themselves constantly. Without their participation, the debate could be sterile and empty, as our arguments become empty every time we face situations in which the ethical relation and Journalism are opposed.

I NOTES

TAM is an airline company. The accident happened with the flight TAM J3054, in July 17 th of 2007 , that caused the death of 187 passengers. 


\section{IREFERENCES}

BOFF, Leonardo. Ética e moral: a busca de fundamentos. 5. Ed. Petrópolis (RJ): Vozes, 2009;

BUCCI, Eugênio. Sobre ética e imprensa. São Paulo: Companhia das Letras, 2002.

CALDAS, Maria das Graças Conde. Ética e cidadania na formação do jornalista. Revista Comunicação \& Sociedade. São Bernardo do Campo: PósComUmesp, a.27, n. 44, p. 85-101, 20 sem. 2005.

CAMARGO, Marculino. Fundamentos de ética geral e profissional. 5. ed. Petrópolis (RJ): Vozes, 2004;

CHRISTOFOLETTI, Rogério. Ética no jornalismo. São Paulo: Contexto, 2008; COSTA, Caio Túlio. Ética, jornalismo e nova mídia - uma moral provisória. Rio de Janeiro: Jorge Zahar Ed., 2009;

GOODWIN, H. Eugene. Procura-se: ética no jornalismo. Rio de Janeiro: Nórdica, 1993;

KARAM, Francisco José Castilhos. Ética, deontologia, formação e profissão: observações sobre o Jornalismo. In: Estudos em Jornalismo e Mídia, Vol. I $N^{0} 1-1^{\circ}$ Semestre de 2004.

KUCINSKI, B. Jornalismo na era virtual. São Paulo: Ed. Fund. Perseu Abramo, 2004.

Edgard Patrício Professor of the Postdegree Program for Education (Programa de Pós-Graduação em Comunicação - PPGCOM), of the Institute of Culture and Art, of Federal University of Ceará (Universidade Federal do Ceará - UFC). Partcipant of the research group Media, Culture and Politics. E-mail: edgard@ ufc.br

RECEIVED ON: 28/09/2013 | APPROVED ON: 10/12/2013 